\title{
SOIL HEAVY METAL CONTAMINATION IN RURAL LAND CONSOLIDATION AREAS IN THE YANGTZE RIVER DELTA, CHINA
}

\author{
Jingjing ZENG ${ }^{1,2}$, Shenglu ZHOU ${ }^{1,2^{\star}}$, Ligang $\mathrm{LV}^{1,2}$, Quanlong $\mathrm{SU}^{1,2}$, Jing WANG ${ }^{2,3}$ \\ ${ }^{1}$ School of Geographic and Oceanographic Sciences, Nanjing University, No. 163, Xianlin Road, Qixia District, \\ Nanjing, Jiangsu Province 210046, China \\ ${ }^{2}$ The Key Laboratory of Coastal Zone Exploitation and Protection, Ministry of Land and Resources, No. 43-8, \\ Beijing West Road, Gulou District, Nanjing, Jiangsu Province 210008, China \\ ${ }^{3}$ Jiangsu Institute of Land Survey and Planning, No. 43-8, Beijing West Road, Gulou District, Nanjing, \\ Jiangsu Province 210008, China
}

Received 18 January 2017; accepted 21 June 2017

\begin{abstract}
Due to the rapid urbanization of the Yangtze River Delta in China, large numbers of formerly rural residents have migrated to the cities. To adjust the structure of rural land use, the government has performed extensive land consolidation. Previous studies indicated that the land consolidation has affected farmland quality to some extent. However, the effect of the land consolidation on farmland heavy metal concentrations has rarely been reported. In this study, the Jintan District was used as an example, and 40 sampling sites of various consolidation types in 4 representative areas of rural land consolidation were selected. Soil samples were collected from these sites, and the heavy metal concentrations were analyzed. We used multivariate methods of correlation analysis and principal component analysis to study the conditions and sources of the heavy metal contamination in the soil. The results indicate that the mean concentrations of $\mathrm{Cd}$, $\mathrm{Hg}, \mathrm{Ni}, \mathrm{Cu}$, and $\mathrm{Zn}$ in the soil all exceeded the background values. The mean concentration of $\mathrm{Cd}$ was $0.409 \mathrm{mg} / \mathrm{kg}$, and the enrichment factor (EF) was 4.54, making Cd the most prevalent heavy metal soil contaminant in the study area. The enrichment of soil heavy metals varied among the various representative areas. Suburban areas surrounding the central cities were mainly enriched in $\mathrm{Hg}$, with an EF of 6.20. The comprehensive development zone displayed enrichment in $\mathrm{Cd}$, with an EF of 7.79. The heavy metal concentrations in the soil also differed depending on the type of land consolidation. The reclaimed soil of rural settlements contained high levels of $\mathrm{Cd}$ and $\mathrm{Zn}$, with EFs of 7.25 and 2.52, respectively, which were related to the land use before the land consolidation. The soil heavy metals of the study area were affected by both human activity and natural background contamination.
\end{abstract}

Keywords: enrichment factor, land consolidation, potential ecology risk, reclamation of rural settlements, soil heavy metal, Yangtze River Delta.

\section{Introduction}

The Yangtze River Delta is currently the most rapidly developing region in China and has the largest GDP and greatest development potential (Chen 2007). With the rapid growth of the regional economy, urbanization in the Yangtze River Delta is also entering the middle and late stages of development (Gu et al. 2011; Wu et al. 2014). Rapid urbanization causes the migration of rural residents to cities. The government transforms rural regions via industrialization and agricultural intensification, which causes heavy rural farmland occupation and affects the rural land use structure and types (Long et al. 2007; Yan et al. 2015). To promote harmonic development of the rural economy and society and to achieve a balance between farmland occupation and compensation, the government promotes numerous land consolidation projects (Tang et al. 2015), including a series of projects and measures for farmland consolidation, farmland merging, ditch and road construction, village relocation, and development and reclamation (Zhang et al. 2014; Zheng et al. 2016).

Researchers in China and abroad have studied the soil in land consolidation zones. Several studies of the soil properties in mining reclamation zones have revealed variations in the soil properties in these zones and their influencing factors (Esmaeili et al. 2014; Insam, Domsch

*Corresponding author. E-mail: zhousl@nju.edu.cn

This is an Open Access article distributed under the terms of the Creative Commons Attribution License (http://creativecommons.org/licenses/by/4.0/), which permits unrestricted use, distribution, and reproduction in any medium, provided the original author and source are credited. 
1988; Ji et al. 2017; Mukhopadhyay et al. 2014). Mukhopadhyay et al. (2014) reported that the soil properties in a certain mining reclamation zone improved with time following the reclamation and that the soil could be remedied to some extent via long-term reclamation projects. Insam and Domsch (1988) showed that the ratio between soil microbial biomass carbon and soil organic carbon could be used as an index for evaluating the results of mining reclamation. The effects of human activity on soil properties during land consolidation have also drawn considerable attention (Mace, Amrhein. 2001; Wang et al. 2014). Previous studies evaluated the effects of fertilization and irrigation on the soil properties in these zones. Mace and Amrhein (2001) reported that irrigation water applied during the rainy season had a negative impact on the soil structure in land consolidation zones. In addition, numerous researchers have conducted systematic studies of land consolidation and reclamation measures and their benefits (Demetriou et al. 2012; Liu et al. 2013; Sheoran et al. 2010; Uyan 2016).

With rapid urbanization, industrialization, and agriculture intensification, the soil quality and health issues in the Yangtze River Delta have become more prominent and have limited the rapid development of the regional economy and severely affected the safety of agricultural products and human health (Zhong et al. 2011). Previous studies have shown that land consolidation projects can affect the soil in project zones to some extent (Fellet et al. 2011). However, studies of their effects on soil heavy metal concentrations are limited, and their specific effects and mechanisms remain unclear. The Jintan District is a representative densely populated region in the Yangtze River Delta. The urbanization rate exceeds 55\%, and its natural conditions and economic development are representative of the Yangtze River Delta. The district recently promoted several land consolidation projects as part of the Ten Thousand Acres of Fertile Farmland project. Previous studies indicated that the soil in this region has been contaminated by heavy metals to some extent (Hao et al. 2009). Numerous studies have assessed the soil heavy metal contamination in this region (Zhao et al. 2010). However, studies of the soil heavy metal concentrations associated with various types of land consolidation are rare. Therefore, in this study, the Jintan District was selected as the study area, the soil heavy metal contamination associated with various land consolidation types in representative land consolidation zones was assessed, and its sources were analyzed. This study provides scientific data on the consolidation and development of farmland in the study area.

\section{Materials and methods}

\subsection{Study area}

The Jintan District is located in southern Jiangsu Province, northwest of the Yangtze River Delta, at $31^{\circ} 33^{\prime} 42^{\prime \prime}$ $31^{\circ} 53^{\prime} 22^{\prime \prime} \mathrm{N}, 119^{\circ} 17^{\prime} 45^{\prime \prime}-119^{\circ} 44^{\prime} 59^{\prime \prime} \mathrm{E}$. The northeastern portion is a hilly region of high relief that transitions to the southeastern plain. The regional climate is characterized by the northern subtropical monsoon. The annual frost-free period spans 226 days, the annual mean temperature is $15.3^{\circ} \mathrm{C}$, and the annual mean precipitation is $1063.6 \mathrm{~mm}$. The annual mean number of rainy days is 124.2 , the mean wind velocity is $2.9 \mathrm{~m} / \mathrm{s}$, and the annual mean duration of sunshine is 2033.8 hours. Recently, the Jintan District performed numerous land consolidation projects, including two primary types, i.e., rural settlement reclamation and farmland consolidation, to increase the amount of farmland and to improve its quality.

To compare the soil heavy metal concentrations in representative land consolidation zones, soil sampling sites were selected in locations of various land consolidation types in four representative zones. We collected soil samples and analyzed the concentrations of $\mathrm{Hg}, \mathrm{As}, \mathrm{Pb}, \mathrm{Cd}$, $\mathrm{Cr}, \mathrm{Ni}, \mathrm{Cu}$, and $\mathrm{Zn}$ (Figure 1). The four selected sampling zones are as follows. The village of Dongpu is located in Zhiqianzhen, Jintan District, and is characterized by flat topography and a dense network of waterways. The industrial and agricultural development and transportation conditions are regarded as adequate. This area is a key zone in the "Ten Thousand Acres of Fertile Farmland" project, and the land consolidation project is comprehensive and contains several land consolidation types. The village of Shangruan is located in Xuebuzhen, Jintan District in a hilly region in the suburbs of the Jintan District. It is a modern agricultural area, and land consolidation has been performed only in a few areas. The village of Xuxiang is located in Jinchengzhen, in the suburbs of the Jintan District. Land consolidation has been performed only in a few areas. The village of Xixi is located in Dengguan Village, Jintan District, and is characterized by flat topography, a dense network of waterways, and extensive agricultural development. This area features severe nonpoint agricultural pollution, and hosts several chemical plants, resulting in severe heavy metal soil contamination. Land

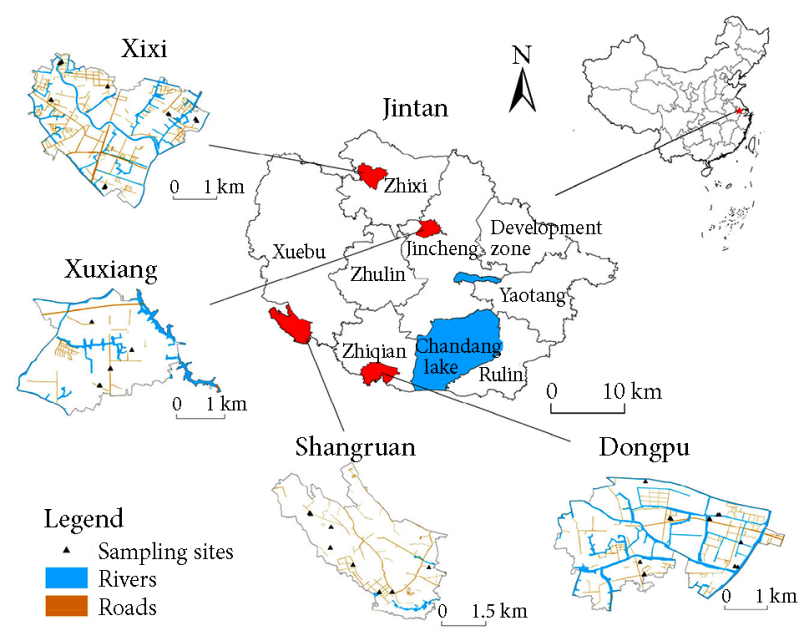

Figure 1 . The study area and sampling sites 
consolidation projects of rural settlement reclamation and farmland consolidation are comprehensively promoted in this area.

\subsection{Soil sampling}

We selected 40 representative land consolidation soil sampling sites in the Jintan District in Jiangsu Province. The sampling sites were selected based on administrative boundaries, soil types, land consolidation types, and regions to ensure that they were representative. We sampled 13 sites in the Dongpu comprehensive development zones, including 5 rural settlement reclamation sites, 4 farmland consolidation sites, and 4 farmland sites, as an external land consolidation control group. We sampled 9 sites in the village of Shangruan that were representative of modern agricultural parks, including 6 farmland consolidation sites and 3 farmland sites, as an internal land consolidation control group. We sampled 11 sites in Xixi that were representative of modern industrial parks, including 4 rural settlement reclamation sites, 4 farmland consolidation sites, and 3 farmland sites, as an external land consolidation control group. We sampled 7 sites in Xuxiang that were representative of suburbs of the central cities, including 5 farmland consolidation sites and 2 farmland sites, as an internal land consolidation control group. The soil type in the study area is mainly paddy soil, and it was mainly composed of clay. One soil sample spanning the depth interval of $0 \sim 20 \mathrm{~cm}$ was collected at each sampling location. We collected soil samples from 5 points in a quincunx pattern, composited them, and repeatedly split each composite by quartering until a sample weight of approximately $1 \mathrm{~kg}$ was achieved. We placed the samples in sample bags, labeled them, and shipped them to our laboratory for analysis. At each sampling location, the coordinates were recorded using GPS, and details of the surrounding environment were recorded.

The samples were processed individually. We crumbled and naturally dried the samples and removed rocks and visible plant residues. We then crushed the samples, passed them through 20-mesh, 60-mesh, and 100-mesh nylon sieves according to the requirements of the testing equipment, and bagged them. The concentrations of $\mathrm{Hg}$ and As were measured using reduction-gasification atomic fluorescence spectrometry. The concentrations of $\mathrm{Cr}, \mathrm{Cu}$, $\mathrm{Ni}$, and $\mathrm{Pb}$ were measured using $\mathrm{HF}-\mathrm{HNO}_{3}-\mathrm{HClO}_{4}$ digestion and inductively coupled plasma atomic emission spectrometry (Li et al. 2008). The total Cd content was measured using $\mathrm{HF}-\mathrm{HNO}_{3}-\mathrm{HClO}_{4}$ digestion and graphite furnace atomic absorption spectrometry. The total $\mathrm{Zn}$ content was measured using $\mathrm{HF}-\mathrm{HNO}_{3}-\mathrm{HClO}_{4}$ digestion and atomic absorption spectrophotometry (Wu et al. 2010).

\subsection{Data analysis}

The soil heavy metal contamination was assessed using the enrichment factor (EF) (Elias, Gbadegesin 2011; Kowalska et al. 2016; Mazurek et al. 2016) and the potential ecological risk index (RI) (Håkanson 1980; Kowalska et al. 2016). The EF is the ratio of the concentration of a contaminant in a medium to the background value of the contaminant (Table 1). The background value was based on the reference value of soil heavy metal concentrations in Jiangsu Province. The RI could comprehensively assess the ecological risk of soil heavy metal enrichment in an area, using the following formula:

$$
R I=\sum_{i=1}^{n} E_{r}^{i}=\sum_{i=1}^{n} T_{r}^{i} \times C_{p}^{i},
$$

where $\mathrm{n}$ represents the number of studied heavy metals, $E_{r}{ }^{i}$ represents the single index of ecological risk factor, $T_{r}{ }^{i}$ represents the toxicity response coefficient of heavy metals (Håkanson 1980), and $C_{p}{ }^{i}$ represents the single pollution index of heavy metal using reference data from Liao et al. (2011). The RI classes are shown in Table 2.

The least significant difference method (LSD) was used to test the significance of the differences in the heavy metal concentrations. Principal component analysis (PCA) is a statistical method for analyzing primary information. PCA results can reflect the majority of the information of multiple original variables via data simplification (Pereira et al. 2016; Pouyat et al. 2007; Zhang 2006). In this study, PCA was used to reduce the dimensions of the variables ( $\mathrm{Ha}$ et al. 2014) and to evaluate the correlations and differences among the soil heavy metal concentrations in the study area (Wang 2008). The data were rotated to obtain the principal vectors using the maximum variance method in the calculation, based onindividual eigenvalue contributions of $10 \%$ and the accumulative eigenvalue contributions exceeding $70 \%$, to further analyze the conditions of heavy metal soil contamination. The mean calculation, difference analysis, and PCA of the soil heavy metal concentrations were conducted using the statistical software SPSS 22.0. The figures were prepared using Excel 2013 and OriginPro.

Table 1. Classes of enrichment factor

\begin{tabular}{|c|l|l|l|l|l|}
\hline $\mathrm{EF}_{\mathrm{i}}$ & \multicolumn{1}{|c|}{$\mathrm{EF}_{\mathrm{i}} \leq 2$} & \multicolumn{1}{|c|}{$2<\mathrm{EF}_{\mathrm{i}} \leq 5$} & \multicolumn{1}{|c|}{$5<\mathrm{EF}_{\mathrm{i}} \leq 20$} & \multicolumn{1}{c|}{$20<\mathrm{EF}_{\mathrm{i}} \leq 40$} & $\mathrm{EF}_{\mathrm{i}}>40$ \\
\hline Enrichment level & minimal & moderate & significant & very high & extremely high \\
\hline
\end{tabular}

Table 2. Classes of potential ecological risk

\begin{tabular}{|l|l|l|l|l|l|}
\hline \multicolumn{1}{|c|}{ RI } & \multicolumn{1}{|c|}{$\mathrm{RI} \leq 90$} & \multicolumn{1}{c|}{$90<\mathrm{RI} \leq 180$} & \multicolumn{1}{c|}{$180<\mathrm{RI} \leq 360$} & \multicolumn{1}{c|}{$360<\mathrm{RI} \leq 720$} & \multicolumn{1}{c|}{$\mathrm{RI}>720$} \\
\hline risk level & low & moderate & high & very high & extremely high \\
\hline
\end{tabular}




\section{Results and discussions}

\subsection{Overall heavy metal concentrations in the soil}

Table 3 shows that the mean concentrations of $\mathrm{Hg}$, $\mathrm{As}, \mathrm{Pb}, \mathrm{Cd}, \mathrm{Cr}, \mathrm{Ni}, \mathrm{Cu}$, and $\mathrm{Zn}$ in the four representative land consolidation zones in the study area were $0.111 \mathrm{mg} / \mathrm{kg}, 9.4 \mathrm{mg} / \mathrm{kg}, 26.8 \mathrm{mg} / \mathrm{kg}, 0.409 \mathrm{mg} / \mathrm{kg}$, $75.8 \mathrm{mg} / \mathrm{kg}, 31.3 \mathrm{mg} / \mathrm{kg}, 33.4 \mathrm{mg} / \mathrm{kg}$, and $108.7 \mathrm{mg} / \mathrm{kg}$, respectively. Compared with the background levels, the mean concentrations of $\mathrm{Hg}$ and $\mathrm{Cd}$ were significantly elevated, while those of $\mathrm{Ni}, \mathrm{Cu}$, and $\mathrm{Zn}$ were slightly elevated, indicating that the concentrations were significantly affected by human activity and external factors. The concentrations of $\mathrm{Cd}, \mathrm{Cu}$ and $\mathrm{Zn}$ were 2.03, 1.51, and 1.34 times higher, respectively, than the mean concentrations of these elements in farmland soil in Yangtze River Delta (Shao et al. 2016). Compared with a reclaimed coastal area in Cixi, China, the study area featured similar concentrations of $\mathrm{Pb}$ and $\mathrm{Zn}$ but slightly higher concentrations of $\mathrm{Ni}$ and $\mathrm{Cu}$ (Wang et al. 2014). Compared with agricultural soils in the Argolida basin in the Mediterranean region, the study area featured concentrations of $\mathrm{As}, \mathrm{Pb}$ and $\mathrm{Zn}$ that were $1.35,1.36$, and 1.45 times higher, respectively, but slightly lower concentrations of Cd, $\mathrm{Cr}$ and $\mathrm{Ni}$ (Kelepertzis 2014). Compared with agricultural soils in the Isfahan industrial zone in Iran, the study area featured similar concentrations of $\mathrm{Cd}, \mathrm{Cu}$ and $\mathrm{Zn}$ but concentrations of $\mathrm{Pb}, \mathrm{Cr}, \mathrm{Ni}$ that were $22.5 \%, 11.8 \%$, and $52.7 \%$ lower, respectively (Esmaeili et al. 2014). In general, the level of soil heavy metal contamination in the study area was mostly similar to that in the areas mentioned above, but the concentrations of $\mathrm{Cd}$ and $\mathrm{Zn}$ were relatively higher.

Previous studies indicated that $\mathrm{Cd}$ is associated with strong biological toxicity and the environmental risks (Ratha, Sahu 1993). In the study area, the EF value of $\mathrm{Cd}$ was higher than those of the other heavy metals. Therefore, controlling and mitigating Cd contamination should be an important objective of subsequent land consolidation in the study area. The coefficient of variation (CV) reflects the variation in a data set. According to the classification scheme of Wilding (1985), the levels of $\mathrm{As}, \mathrm{Pb}$, $\mathrm{Cr}, \mathrm{Ni}$, and $\mathrm{Cu}$ displayed intermediate levels of variation $(15 \%<\mathrm{CV}<36 \%)$, and the levels of $\mathrm{Hg}$, Cd, and $\mathrm{Zn}$ displayed high levels of variation $(\mathrm{CV}>36 \%)$. The levels of $\mathrm{Cd}$ in particular yielded a CV much greater than those of the other heavy metals, indicating that the concentrations of $\mathrm{Hg}, \mathrm{Cd}$ and $\mathrm{Zn}$ varied greatly within the study area. Thus, the distributions of $\mathrm{Hg}, \mathrm{Cd}$, and $\mathrm{Zn}$ in the study area were extremely heterogeneous, possibly due to anthropogenic point-source contamination.

Table 4 shows that some of the EF values in the representative land consolidation zones in the study area were larger than 1, indicating that the heavy metals were enriched in the soil to some extent in the study area. The EF values of $\mathrm{Cd}$ were higher than 5 (indicating significant enrichment levels) in the rural settlement reclamation and farmland consolidation zone in the comprehensive development area of Dongpu and in the rural settlement reclamation zone in Xixi modern industrial park. The EF values in the Xuxiang suburban area of the central cities were also higher than 5 , indicating significant enrichment levels. The EF values of $\mathrm{Zn}$ in the rural settlement reclamation zones in Dongpu, Xixi and Xuxiang were higher than 2, i.e., moderate enrichment levels. Most of the RI values were higher than 180 , indicating that a certain degree of potential ecological risk existed in the study area. The RI value of the control group soil in the Xuxiang suburban area of the central cities was the highest because the concentration of the highly toxic heavy metal $\mathrm{Hg}$ was significantly higher than the background level. The RI values of the rural settlement reclamation and farmland consolidation zones were also high, and the ecological risk mainly came from the significantly enriched Cd in the soil. In general, the potential ecology risk in the Dongpu comprehensive development zone and Xuxiang suburban area of the central cities was high, while the potential ecological risk in the Xixi modern industrial park and Shangruan modern agricultural park was relatively low.

Table 3. Statistical characteristics of heavy metal concentrations in the study area and comparisons with other similar areas

\begin{tabular}{|c|c|c|c|c|c|c|c|c|}
\hline \multirow{2}{*}{ Element } & \multirow{2}{*}{$\begin{array}{l}\text { Mean } \pm \text { SD } \\
(\mathrm{mg} / \mathrm{kg})\end{array}$} & \multirow{2}{*}{$\begin{array}{l}\mathrm{CV} \\
(\%)\end{array}$} & \multirow{2}{*}{$\begin{array}{c}\text { Soil } \\
\text { background } \\
(\mathrm{mg} / \mathrm{kg})\end{array}$} & \multirow{2}{*}{$\mathrm{EF}$} & \multicolumn{4}{|c|}{$\begin{array}{l}\text { Mean concentrations }(\mathrm{mg} / \mathrm{kg}) \text { of heavy metals in } \\
\text { agricultural soils from various areas around the world }\end{array}$} \\
\hline & & & & & $\begin{array}{c}\text { Yangtze } \\
\text { Delta, China }\end{array}$ & $\begin{array}{l}\text { Cixi, } \\
\text { China }\end{array}$ & $\begin{array}{c}\text { Argolida, } \\
\text { Greece }\end{array}$ & $\begin{array}{l}\text { Isfahan, } \\
\text { Iran }\end{array}$ \\
\hline $\mathrm{Hg}$ & $0.111 \pm 0.076$ & 68.47 & 0.03 & 3.70 & - & - & - & - \\
\hline As & $9.4 \pm 1.846$ & 19.72 & 9.91 & 0.95 & - & - & 6.95 & - \\
\hline $\mathrm{Pb}$ & $26.8 \pm 4.486$ & 16.71 & 22.6 & 1.19 & 35.12 & 25.8 & 19.74 & 34.6 \\
\hline $\mathrm{Cd}$ & $0.409 \pm 0.456$ & 111.49 & 0.09 & 4.54 & 0.201 & - & 0.54 & 0.43 \\
\hline $\mathrm{Cr}$ & $75.8 \pm 11.441$ & 15.09 & 76.4 & 0.99 & - & - & 83.12 & 85.9 \\
\hline $\mathrm{Ni}$ & $31.3 \pm 6.883$ & 21.98 & 33.7 & 0.93 & 29.67 & 28.6 & 146.8 & 66.2 \\
\hline $\mathrm{Cu}$ & $33.4 \pm 9.774$ & 29.23 & 24.0 & 1.39 & 22.16 & 24.1 & 74.68 & 35.7 \\
\hline $\mathrm{Zn}$ & $108.7 \pm 74.712$ & 68.71 & 65.8 & 1.65 & 81.07 & 108 & 74.88 & 111.5 \\
\hline
\end{tabular}


Table 4. Soil heavy metal contamination in the study areas

\begin{tabular}{|c|c|c|c|c|c|c|c|c|c|c|}
\hline $\begin{array}{l}\text { Administrative } \\
\text { village }\end{array}$ & $\begin{array}{l}\text { Land conso- } \\
\text { lidation type }\end{array}$ & $\mathrm{EF}_{\mathrm{Hg}}$ & $\mathrm{EF}_{\mathrm{As}}$ & $\mathrm{EF}_{\mathrm{Pb}}$ & $\mathrm{EF}_{\mathrm{Cd}}$ & $\mathrm{EF}_{\mathrm{Cr}}$ & $\mathrm{EF}_{\mathrm{Ni}}$ & $\mathrm{EF}_{\mathrm{Cu}}$ & $\mathrm{EF}_{\mathrm{Zn}}$ & RI \\
\hline \multirow{3}{*}{$\begin{array}{l}\text { Dongpu } \\
\text { comprehensive } \\
\text { development } \\
\text { zone }\end{array}$} & Reclamation & 2.93 & 0.81 & 1.30 & 10.09 & 1.05 & 1.04 & 1.36 & 2.73 & 451.33 \\
\hline & Consolidation & 3.20 & 0.71 & 1.29 & 8.14 & 1.16 & 1.16 & 1.61 & 1.82 & 403.74 \\
\hline & Control & 4.60 & 0.87 & 1.25 & 3.89 & 1.05 & 1.03 & 1.53 & 1.16 & 331.71 \\
\hline \multirow{2}{*}{$\begin{array}{l}\text { Shangruan } \\
\text { modern } \\
\text { agricultural park }\end{array}$} & Consolidation & 1.90 & 0.95 & 1.11 & 2.90 & 0.85 & 0.69 & 1.05 & 1.21 & 189.66 \\
\hline & Control & 1.84 & 1.03 & 1.09 & 2.38 & 0.91 & 0.62 & 0.97 & 1.14 & 171.66 \\
\hline \multirow{3}{*}{$\begin{array}{l}\text { Xixi modern } \\
\text { industrial park }\end{array}$} & Reclamation & 3.57 & 1.01 & 1.18 & 5.50 & 0.97 & 0.93 & 1.45 & 2.31 & 339.95 \\
\hline & Consolidation & 2.63 & 1.14 & 1.14 & 2.11 & 1.07 & 1.08 & 1.47 & 1.24 & 201.73 \\
\hline & Control & 4.87 & 0.98 & 1.21 & 3.07 & 0.96 & 0.93 & 1.64 & 1.55 & 319.07 \\
\hline \multirow{2}{*}{$\begin{array}{l}\text { Xuxiang } \\
\text { suburban area of } \\
\text { the central cities }\end{array}$} & Consolidation & 5.57 & 1.12 & 1.19 & 4.36 & 1.08 & 1.00 & 1.45 & 2.03 & 387.19 \\
\hline & Control & 10.07 & 0.85 & 1.04 & 2.29 & 0.93 & 0.83 & 1.72 & 1.01 & 500.82 \\
\hline
\end{tabular}

* "Reclamation" represents rural settlement reclamation, "consolidation" represents farmland consolidation, and "control" represents the farmland control group in the representative zones.

\subsection{Differences in heavy metal concentrations between representative land consolidation zones}

Based on the significance tests of the differences in soil heavy metal concentrations in the representative land consolidation zones (Table 5), many differences among the soil heavy metal concentrations of the four representative zones were significant $(\mathrm{P}<0.05)$. Therefore, the differences among the four selected representative zones accurately reflect the soil characteristics of the representative zones. The Hg concentration in the village of Xuxiang, representing an area of rapid urbanization, differed significantly from that in the other three representative zones. The concentrations of $\mathrm{Cr}, \mathrm{Ni}$, and $\mathrm{Cu}$ in the soil in the village of Shangruan, representing modern agricultural parks, differed significantly from those in the other three representative zones.

Figure 2 shows that the $\mathrm{Hg}$ concentration in the village of Xuxiang was far higher than that in the other three representative zones, and its EF was 6.20, representing significant enrichment. Previous studies indicated that there is a high probability that suburban areas display anomalous $\mathrm{Hg}$ distributions due to anthropogenic emissions, particularly coal burning (Guédron et al. 2016). The soil Cd concentration in the village of Dongpu was significantly higher than that in the other three representative zones, and had an EF of 7.79, representing significant enrichment. The concentrations of $\mathrm{Cr}, \mathrm{Ni}$, and $\mathrm{Cu}$ in the village of Shangruan were lower than those in the other three representative zones. The heavy metal concentrations were relatively high in the villages of Dongpu and Xixi, where the degree of land consolidation was high. The heavy metal concentrations were relatively low in the villages of Shangruan and Xuxiang, where the degree of land consolidation was low. In the village of Dongpu, the concentrations of $\mathrm{Cd}$ and $\mathrm{Zn}$ were far higher than the mean levels in the four representative zones. The mean $\mathrm{Cd}$ concentration was $0.653 \mathrm{mg} / \mathrm{kg}$ and had a CV of $95.893 \%$. The mean Zn concentration was $126.055 \mathrm{mg} / \mathrm{kg}$, and had a CV of $78.364 \%$. These data indicate that the concentrations of $\mathrm{Cd}$ and $\mathrm{Zn}$ in the soil in the village of Dongpu varied significantly. In Xixi, the mean concentrations of $\mathrm{Ni}, \mathrm{Cu}$, and $\mathrm{Zn}$ in the soil exceeded the mean levels in the four representative zones. Furthermore, the $\mathrm{CV}$ of $\mathrm{Zn}$ was high, with a value of $59.589 \%$. Although the mean concentration of $\mathrm{Cd}$ $(0.312 \mathrm{mg} / \mathrm{kg})$ was lower than the mean, the CV was high, with a value of $86.420 \%$. In Shangruan, the mean concentrations of $\mathrm{As}$ and $\mathrm{Pb}$ in the soil exceeded the means in the four representative zones, but the CV values were small. Therefore, these high concentrations might be widely distributed in this village. Although the concentrations of $\mathrm{Cd}$

Table 5. Significance tests of soil heavy metal concentrations in representative areas

\begin{tabular}{|l|c|c|c|c|c|c|c|c|}
\hline & $\mathrm{Hg}$ & $\mathrm{As}$ & $\mathrm{Pb}$ & $\mathrm{Cd}$ & $\mathrm{Cr}$ & $\mathrm{Ni}$ & $\mathrm{Cu}$ & $\mathrm{Zn}$ \\
\hline Dongpu-Xixi & -0.008 & $-2.199^{\star}$ & 2.264 & 0.340 & 6.704 & 3.156 & -1.334 & 15.961 \\
\hline Dongpu-Shangruan & 0.054 & -1.303 & $4.524^{\star}$ & $0.407^{\star}$ & $18.184^{\star}$ & $12.926^{\star}$ & $10.996^{\star}$ & 48.759 \\
\hline Dongpu-Xuxiang & $-0.064^{\star}$ & $-2.386^{\star}$ & 2.458 & 0.305 & 1.854 & 3.240 & -0.365 & 8.015 \\
\hline Xixi-Shangruan & 0.062 & 0.896 & 2.260 & 0.066 & $11.481^{\star}$ & $9.770^{\star}$ & $12.330^{\star}$ & 32.799 \\
\hline Xixi-Xuxiang & $-0.056^{\star}$ & -0.187 & 0.194 & -0.035 & -4.849 & 0.084 & 0.969 & -7.945 \\
\hline Shangruan-Xuxiang & $-0.118^{\star}$ & -1.083 & -2.065 & -0.102 & $-16.330^{\star}$ & $-9.686^{\star}$ & $-11.362^{\star}$ & -40.744 \\
\hline
\end{tabular}

* Significant levels, $\mathrm{P}<0.05$ 

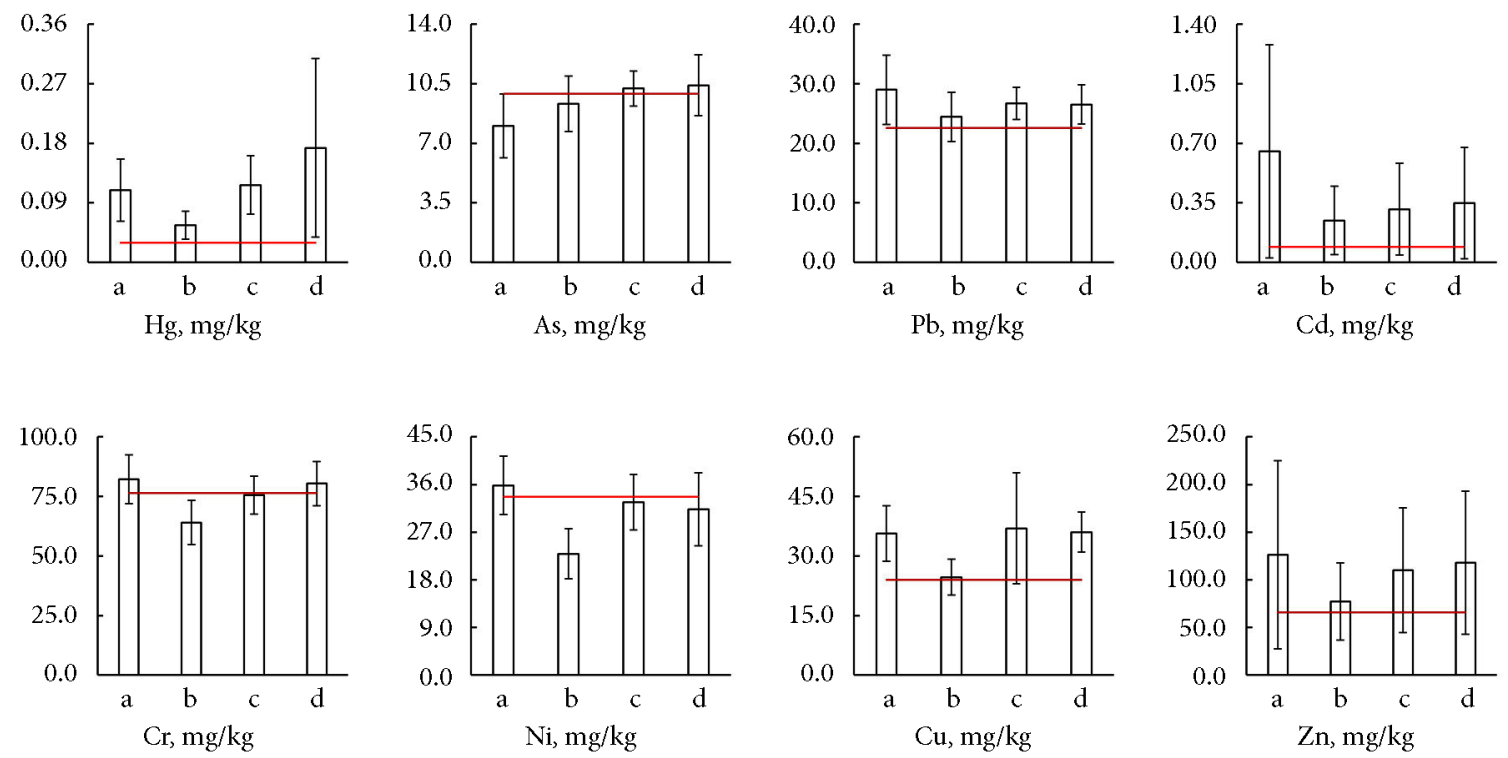

Figure 2. Heavy metal concentrations in representative areas (a: Dongpu; b: Shangruan; c: Xixi; d: Xuxiang; red lines denote background values)

and $\mathrm{Zn}$ were low, the $\mathrm{CV}$ values were high, i.e., $79.314 \%$ and $53.540 \%$, respectively. In Xuxiang, the concentrations of the eight heavy metals in the soil were all low, indicating that the contamination in this village was low. However, the $\mathrm{CV}$ values of the concentrations of $\mathrm{Hg}, \mathrm{Cd}$, and $\mathrm{Zn}$ were high. In the four representative zones, the $\mathrm{CV}$ values of the concentrations of $\mathrm{Cd}$ and $\mathrm{Zn}$ were high, suggesting that the farmland contamination originated from point sources of $\mathrm{Cd}$ and $\mathrm{Zn}$.

\subsection{Differences in soil heavy metal concentrations among different land consolidation types}

Based on the significant tests, the differences among the soil heavy metal concentrations associated with different land consolidation types (Table 6) were not significant $(\mathrm{P}<0.05)$ except for those of $\mathrm{Hg}, \mathrm{Cu}$, and $\mathrm{Zn}$. The concentrations of $\mathrm{Hg}$ and $\mathrm{Cu}$ in the farmland control group were high overall. The $\mathrm{Zn}$ concentration in the rural settlement reclamation soil was far higher than that in the farmland consolidation soil and the control group. The $\mathrm{Zn}$ concentration in the rural settlement reclamation soil differed significantly from that in the farmland consolidation soil and the control group, indicating that the $\mathrm{Zn}$ concentrations in the study area might be related to the type of land use.

Figure 3 shows that the soil heavy metal concentrations associated with the different land consolidation types varied along a clear gradient. The mean concentrations of $\mathrm{Pb}, \mathrm{Cd}, \mathrm{Cr}, \mathrm{Ni}$, and $\mathrm{Zn}$ ranked in the order of rural settlement reclamation $>$ farmland consolidation $>$ farmland control group. The EF values of $\mathrm{Cd}$ and $\mathrm{Zn}$ in the rural settlement reclamation soil were 7.25 and 2.52 , respectively, which exceeded the background levels and were significantly higher than those of the farmland consolidation soil and control group. Although the levels of $\mathrm{Pb}$, $\mathrm{Cr}$, and $\mathrm{Ni}$ also conformed to this pattern, the differences between the land consolidation types were small. The EF values of $\mathrm{Hg}$ in the land consolidation types in the study area all exceeded 2, and the EF of the control group was 5.32, which was higher than that in the other areas. The concentrations of As and $\mathrm{Cu}$ did not vary distinctly among the different types of land consolidation.

Based on the data in Table 6 and Figure 3, the soil heavy mental concentrations associated with the different land consolidation types generally followed the pattern of rural settlement reclamation $>$ farmland consolidation $>$ farmland control group. The differences among $\mathrm{Hg}, \mathrm{Cd}$, and $\mathrm{Zn}$ were significant. The concentrations of $\mathrm{Zn}$ and $\mathrm{Cd}$ in the rural settlement reclamation soil were higher than the background value and differed significantly from those of the farmland consolidation soil and control group, indicating that these elevated concentrations might have been due to human activity. Previous studies indicated that

Table 6. Significance tests for soil heavy metal concentrations associated with soil reclamation areas

\begin{tabular}{|l|c|c|c|c|c|c|c|c|}
\hline & $\mathrm{Hg}$ & $\mathrm{As}$ & $\mathrm{Pb}$ & $\mathrm{Cd}$ & $\mathrm{Cr}$ & $\mathrm{Ni}$ & $\mathrm{Cu}$ & $\mathrm{Zn}$ \\
\hline Reclamation-consolidation & -0.001 & -1.089 & 2.377 & 0.349 & 2.606 & 3.463 & 3.336 & $59.880^{\star}$ \\
\hline Reclamation-control & -0.063 & -0.400 & 0.905 & 0.390 & 1.277 & 0.766 & -4.210 & $71.756^{\star}$ \\
\hline Consolidation-control & $-0.062^{\star}$ & 0.689 & -1.47 & 0.041 & -1.328 & -2.697 & $-7.547^{\star}$ & 11.876 \\
\hline
\end{tabular}


elevated $\mathrm{Zn}$ and $\mathrm{Cd}$ concentrations were present in the old residential zones (Zhang et al. 2015). Thus the $\mathrm{Zn}$ and $\mathrm{Cd}$ enrichment in the rural settlement reclamation soil in the study area might have been due to human activity predating the land consolidation projects. The soil Hg concentration in the study area was far higher than the background value, probably due to atmospheric dust fall. Atmospheric $\mathrm{Hg}$ emissions from coal burning in Jiangsu Province are high, exceeding $10 \mathrm{t} / \mathrm{a}$ (Jiang et al. 2005); thus, coal burning emissions might be a cause of the widespread elevated $\mathrm{Hg}$ concentrations in the study area.
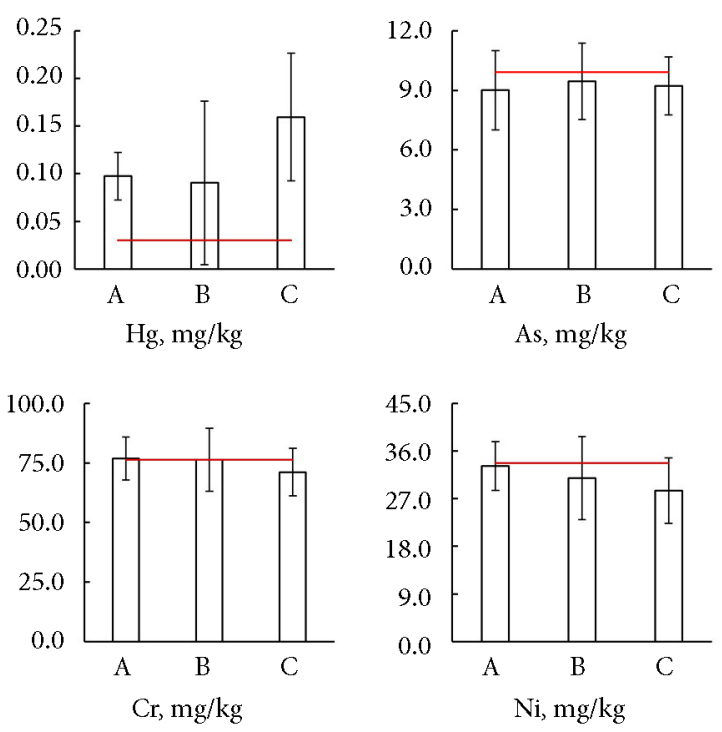

\subsection{Sources of the soil heavy metals in the study area}

Based on Table 5, the soil heavy metal concentrations associated with the representative land consolidation zones differed significantly. Therefore, we used the representative zones as division units and used SPSS to conduct a PCA of the soil heavy metal concentrations in the study area (Table 7). The resulting eigenvectors (Figure 4) were then used to further analyze the sources of the soil heavy metal contamination.
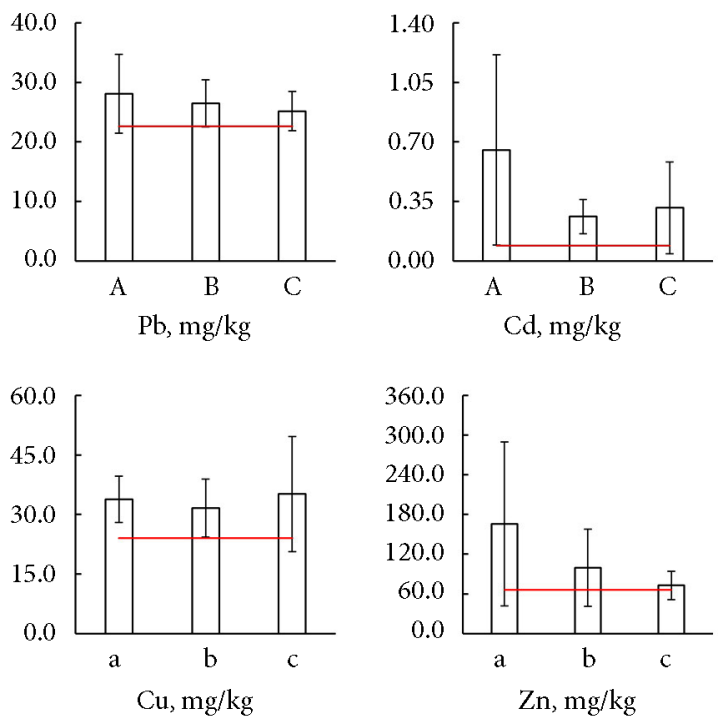

Figure 3. Heavy metal concentrations associated with various types of land reclamation (A: Reclamation; B: Consolidation; C: Control; red lines denote background values)

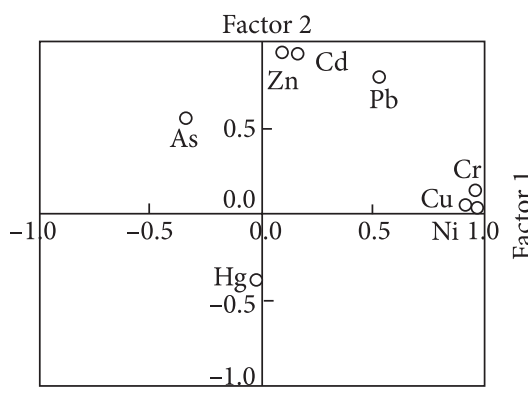

a) Dongpu

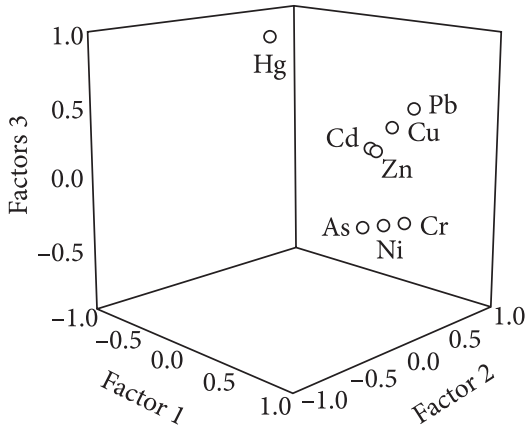

c) Xixi

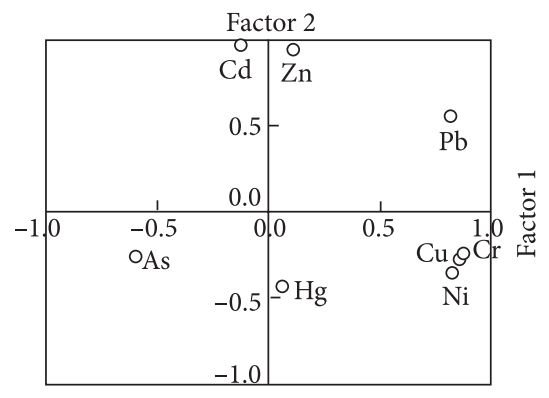

b) Shangruan

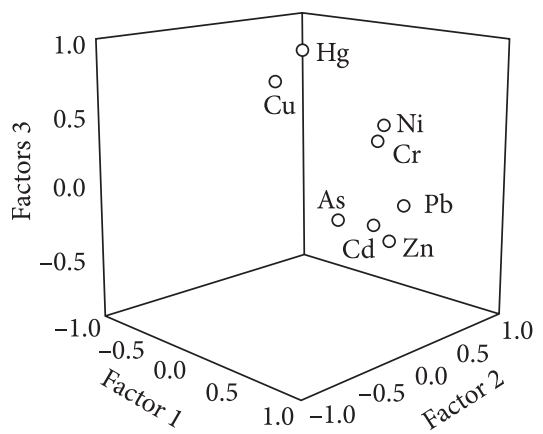

d) Xuxiang

Figure 4. PCA results for the heavy metals in the soils of the four representative areas 
Table 7. Sources of soil heavy metal concentration in the different representative areas

\begin{tabular}{|c|c|c|c|c|c|c|c|c|c|c|}
\hline & \multicolumn{2}{|c|}{ Dongpu } & \multicolumn{2}{|c|}{ Shangruan } & \multicolumn{3}{|c|}{ Xixi } & \multicolumn{3}{|c|}{ Xuxiang } \\
\hline & $\mathrm{PC} 1$ & $\mathrm{PC} 2$ & $\mathrm{PC} 1$ & $\mathrm{PC} 2$ & $\mathrm{PC} 1$ & $\mathrm{PC} 2$ & PC3 & $\mathrm{PC} 1$ & $\mathrm{PC} 2$ & PC3 \\
\hline $\mathrm{Hg}(\mathrm{mg} / \mathrm{kg})$ & -0.02 & -0.38 & 0.06 & -0.43 & -0.27 & 0.03 & 0.94 & -0.06 & 0.06 & 0.93 \\
\hline As $(\mathrm{mg} / \mathrm{kg})$ & -0.34 & 0.56 & -0.60 & -0.26 & 0.77 & -0.13 & -0.19 & -0.32 & 0.73 & -0.51 \\
\hline $\mathrm{Pb}(\mathrm{mg} / \mathrm{kg})$ & 0.53 & 0.80 & 0.81 & 0.55 & 0.43 & 0.76 & 0.44 & 0.99 & -0.06 & 0.05 \\
\hline $\mathrm{Cd}(\mathrm{mg} / \mathrm{kg})$ & 0.16 & 0.94 & -0.13 & 0.98 & -0.14 & 0.98 & -0.01 & 0.94 & -0.30 & -0.06 \\
\hline $\mathrm{Cr}(\mathrm{mg} / \mathrm{kg})$ & 0.97 & 0.15 & 0.86 & -0.24 & 0.96 & 0.10 & -0.17 & -0.12 & 0.94 & 0.12 \\
\hline $\mathrm{Ni}(\mathrm{mg} / \mathrm{kg})$ & 0.97 & 0.03 & 0.82 & -0.35 & 0.93 & -0.12 & -0.14 & -0.10 & 0.97 & 0.21 \\
\hline $\mathrm{Cu}(\mathrm{mg} / \mathrm{kg})$ & 0.92 & 0.05 & 0.85 & -0.26 & 0.79 & 0.10 & 0.46 & -0.52 & 0.25 & 0.61 \\
\hline $\mathrm{Zn}(\mathrm{mg} / \mathrm{kg})$ & 0.10 & 0.95 & -0.01 & 0.92 & -0.11 & 0.98 & -0.02 & 0.89 & -0.07 & -0.22 \\
\hline Contribution (\%) & 46.87 & 28.91 & 41.11 & 31.17 & 41.30 & 33.39 & 15.43 & 48.65 & 22.67 & 18.16 \\
\hline
\end{tabular}

The cumulative variance contributions of the principal components of the four representative land consolidation zones were $76 \%, 73 \%, 90 \%$, and $89 \%$, indicating that the principal components were sufficient to explain the soil heavy metal concentration data in the study area. The heavy metals in the Dongpu comprehensive development zone were divided into two components. The first principal component consisted of $\mathrm{Cr}, \mathrm{Ni}$, and $\mathrm{Cu}$, and the second principal component consisted of $\mathrm{Zn}, \mathrm{Pb}$, and $\mathrm{Cd}$. The heavy metals in the Shangruan modern agricultural park were divided into two components. The first principal component consisted of $\mathrm{Pb}, \mathrm{Cr}, \mathrm{Ni}$, and $\mathrm{Cu}$, and the second principal component consisted of $\mathrm{Cd}$ and $\mathrm{Zn}$. The heavy metals in the Xixi modern industrial park were divided into three components. As, $\mathrm{Cr}, \mathrm{Ni}$, and $\mathrm{Cu}$ were assigned to the first principal component; $\mathrm{Pb}, \mathrm{Cd}$, and $\mathrm{Zn}$ were assigned to the second principal component; and $\mathrm{Hg}$ was assigned to the third principal component. The heavy metals associated with urbanization in Xuxiang were divided into three components. $\mathrm{Pb}, \mathrm{Cd}$, and $\mathrm{Zn}$ were assigned to the first principal component; $\mathrm{As}, \mathrm{Cr}$, and $\mathrm{Ni}$ were assigned to the second principal component; and $\mathrm{Hg}$ and $\mathrm{Cu}$ were assigned to the third principal component.

After combining these data with those in Table 3, we noted that the concentrations of $\mathrm{As}, \mathrm{Cr}$, and $\mathrm{Ni}$ in the study area approximated the soil background values and were therefore little affected by human activity. The distribution depended primarily on the soil characteristics, which is a natural factor. The $\mathrm{Pb}$ and $\mathrm{Cu}$ concentrations were elevated slightly above the background values, indicating that the concentrations of these two heavy metals were affected by human activity to some extent. The Hg, $\mathrm{Cd}$, and $\mathrm{Zn}$ concentrations differed significantly from the background values and were therefore affected by human activity. The first principal component in the analysis of the Dongpu comprehensive development zone and the Shangruan modern agricultural park was associated primarily with natural factors. The second principal component was associated primarily with human factors. Thus, the soil characteristics were an important factor controlling the concentrations in these areas. The first principal component in the analysis of the Xixi modern industrial park was associated primarily with natural factors. The second and third principal components were associated primarily with human factors. The contribution of natural factors to the soil heavy metals in Xixi was $41.30 \%$, whereas human factors contributed $48.82 \%$. These two contributions are approximately equal. The first and third principal components in the analysis of Xuxiang in the suburbs of the central cities were associated primarily with human factors, which contributed $66.81 \%$, indicating that the effects of human activity were significant. In addition, the soil heavy metal concentration in the study area often showed correlations among $\mathrm{Cr}, \mathrm{Ni}$, and $\mathrm{Cu}$ and among $\mathrm{Pb}$, $\mathrm{Cd}$, and $\mathrm{Zn}$. In contrast, the correlations among $\mathrm{Hg}$ and As and the other heavy metals were low. Therefore, the $\mathrm{Cr}, \mathrm{Ni}$, and $\mathrm{Cu}$ concentrations in the soil in the study area might be related to the soil characteristics, whereas the $\mathrm{Pb}$, $\mathrm{Cd}$, and $\mathrm{Zn}$ concentrations might be related to human activity, i.e., land use. The sources of the $\mathrm{Hg}$ possibly include local land use and atmospheric dust fall. The contributions of various sources to the heavy metal concentrations in the study area require further study.

\section{Conclusions}

The concentrations of $\mathrm{Hg}$ and $\mathrm{Cd}$ in the soils of the four representative land consolidation zones were significantly elevated above the corresponding background values, and the concentrations of $\mathrm{Ni}, \mathrm{Cu}$, and $\mathrm{Zn}$ were also enriched to some extent. Therefore, the concentrations of these elements were significantly affected by human activity and external factors.

The heavy metal concentrations in the Shangruan modern agricultural park were the lowest. The environmental quality of the soil in Shangruan was generally good. The soil heavy metals in the Xuxiang suburbs of the central cities were most severely affected by human factors, based on the $\mathrm{Hg}$ enrichment. The concentrations of the heavy metals in the soils of the Xixi modern industrial park were affected by human and natural factors and the concentrations of $\mathrm{Cd}$ and $\mathrm{Zn}$ were high. The heavy metal 
concentrations in the Dongpu comprehensive development zone were controlled primarily by the soil characteristics. However, the concentrations of $\mathrm{Cd}$ and $\mathrm{Zn}$ were elevated.

Widespread $\mathrm{Cd}$ and $\mathrm{Zn}$ enrichment existed in the rural settlement reclamation soil due to human activity in this zone prior to reclamation.

The soil heavy metal concentrations in the study area were controlled by both human activity and natural background effects. Therefore, it is important to control background contamination, improve the soil background quality, and reduce anthropogenic heavy metal emissions during efforts to mitigate soil heavy metal contamination and improve farmland quality in consolidation zones during land consolidation.

\section{Funding}

This work was supported by the Special Fund for Research in the Public Interest of Ministry of Land and Resources [grant number 201511001-03].

\section{Disclosure statement}

The authors declare no conflict of interest.

\section{References}

Chen, X. 2007. A tale of two regions in China rapid economic development and slow industrial upgrading in the Pearl River and the Yangtze River deltas, International Journal of Comparative Sociology 48: 167-201.

https://doi.org/10.1177/0020715207075399

Demetriou, D.; Stillwell. J; See, L. 2012. Land consolidation in Cyprus: why is an integrated planning and decision support system required?, Land Use Policy 29: 131-142.

https://doi.org/10.1016/j.landusepol.2011.05.012

Elias, P.; Gbadegesin, A. 2011. Spatial relationships of urban land use, soils and heavy metal concentrations in Lagos mainland area, Journal of Applied Sciences \& Environmental Management 15(2): 391-399.

Esmaeili, A.; Moore, F.; Keshavarzi, B.; Jaafarzadeh, N.; Kermani, M. 2014. A geochemical survey of heavy metals in agricultural and background soils of the Isfahan industrial zone, Iran, Catena 121: 88-98.

https://doi.org/10.1016/j.catena.2014.05.003

Fellet, G.; Marchiol, L.; Delle Vedove, G.; Peressotti, A. 2011. Application of biochar on mine tailings: effects and perspectives for land reclamation, Chemosphere 83: 1262-1267. https://doi.org/10.1016/j.chemosphere.2011.03.053

Gu, C.; Hu, L.; Zhang, X.; Wang, X.; Guo, J. 2011. Climate change and urbanization in the Yangtze River Delta, Habitat International 35: 544-552.

https://doi.org/10.1016/j.habitatint.2011.03.002

Guédron, S.; Amouroux, D.; Sabatier, P.; Desplanque, C.; Develle, A.-L.; Barre, J.; Feng, C.; Guiter, F.; Arnaud, F.; Reyss, J. L.; Charlet, L. 2016. A hundred year record of industrial and urban development in French Alps combining Hg accumulation rates and isotope composition in sediment archives from Lake Luitel, Chemical Geology 431: 10-19.

https://doi.org/10.1016/j.chemgeo.2016.03.016
Ha, H.; Olson, J. R.; Bian, L.; Rogerson, P. A. 2014. Analysis of heavy metal sources in soil using Kriging interpolation on principal components, Environmental Science \& Technology 48: 4999-5007.

https://doi.org/10.1021/es405083f

Håkanson, L. 1980. An ecological risk index for aquatic pollution control: a sedimentological approach, Water Research 14: 975-1001.

https://doi.org/10.1016/0043-1354(80)90143-8

Hao, X.; Zhou, D.; Huang, D.; Cang, L.; Zhang, H.; Wang, H. 2009. Heavy metal transfer from soil to vegetable in southern Jiangsu Province, China, Pedosphere 19: 305-311. https://doi.org/10.1016/S1002-0160(09)60121-1

Insam, H.; Domsch, K. H. 1988. Relationship between soil organic carbon and microbial biomass on chronosequences of reclamation sites, Microbial Ecology 15: 177-188.

https://doi.org/10.1007/BF02011711

Ji, C.; Zahra, D. N.; Myung, C. J. 2017. Arsenic and heavy metals in paddy soil and polished rice contaminated by mining activities in Korea, Catena 148: 92-100.

https://doi.org/10.1016/j.catena.2016.01.005

Jiang, J.-Z.; Hao, J.-M.; Wu, Y.; David, G. S.; Duan, L.; Tian, H. Z. 2005. Development of mercury emission inventory from coal combustion in China, Environmental Science 2: 34-39 (in Chinese).

Kelepertzis, E. 2014. Accumulation of heavy metals in agricultural soils of Mediterranean: Insights from Argolida basin, Peloponnese, Greece, Geoderma 221-222: 82-90. https://doi.org/10.1016/j.geoderma.2014.01.007

Kowalska, J.; Mazurek, R.; Gasiorek, M.; Setlak, M.; Zaleski, T.; Waroszewski, J. 2016. Soil pollution indices conditioned by medieval metallurgical activity e a case study from Krakow (Poland), Environmental Pollution 218: 1023-1036. https://doi.org/10.1016/j.envpol.2016.08.053

Li, Y.; Gou, X.; Wang, G.; Zhang, Q.; Su, Q. 2008. Heavy metal contamination and source in arid agricultural soil in central Gansu Province, China, Journal of Environmental Sciences 20: 607-612. https://doi.org/10.1016/S1001-0742(08)62101-4

Liao, Q.-L.; Evans, L. J.; Gu, X.; Fan, D.-F.; Jin, Y.; Wang, H. 2011. Geochemical baseline values of elements in soil of Jiangsu Province, Geology China 38: 1363-1378 (in Chinese).

Liu, S. L.; Dong, Y. H.; Li, D.; Liu, Q.; Wang, J.; Zhang, X. L. 2013. Effects of different Terrace protection measures in a sloping land consolidation project targeting soil erosion at the slope scale, Ecological Engineering 53: 46-53.

https://doi.org/10.1016/j.ecoleng.2012.12.001

Long, H.; Tang, G.; Li, X.; Heilig, G. K. 2007. Socio-economic driving forces of land-use change in Kunshan, the Yangtze River Delta economic area of China, Journal of Environmental Management 83: 351-364.

https://doi.org/10.1016/j.jenvman.2006.04.003

Mace, J. E.; Amrhein, C. 2001. Leaching and reclamation of a soil irrigated with moderate SAR waters, Soil Science Society of America Journal 65: 199-204. https://doi.org/10.2136/sssaj2001.651199x

Mazurek, R.; Kowalska, J.; Gasiorek, M.; Zadrozny, P.; Jozefowska, A.; Zaleski, T.; Kepka, W.; Tymczuk, M.; Orłowska, K. 2016. Assessment of heavy metals contamination in surface layers of Roztocze National Park forest soils (SE Poland) by indices of pollution, Chemosphere 1-12 (in press).

Mukhopadhyay, S.; Maiti, S. K.; Masto, R. E. 2014. Development of mine soil quality index (MSQI) for evaluation of reclamation success: a chronosequence study, Ecological Engineering 71: 10-20. https://doi.org/10.1016/j.ecoleng.2014.07.001 
Pereira, J. C.; Azevedo, J. C.; Knapik, H. G.; Burrows, H. D. 2016. Unsupervised component analysis: PCA, POA and ICA data exploring - connecting the dots, Spectrochimica Acta Part A Molecular \& Biomolecular Spectroscopy 165: 69-84. https://doi.org/10.1016/j.saa.2016.03.048

Pouyat, R. V.; Yesilonis, I. D.; Russell-Anelli, J.; Neerchal, N. K. 2007. Soil chemical and physical properties that differentiate urban land-use and cover types, Soil Science Society of America Journal 71: 1010-1019. https://doi.org/10.2136/sssaj2006.0164

Ratha, D. S.; Sahu, B. K. 1993. Source and distribution of metals in urban soil of Bombay, India, using multivariate statistical techniques, Environmental Geology 22: 276-285. https://doi.org/10.1007/BF00767413

Shao, D.; Zhan, Y.; Zhou, W.; Zhu, L. 2016. Current status and temporal trend of heavy metals in farmland soil of the Yangtze River Delta Region: Field survey and meta-analysis, Environmental Pollution 219: 329-336. https://doi.org/10.1016/j.envpol.2016.10.023

Sheoran, V.; Sheoran, A.; Poonia, P. 2010. Soil reclamation of abandoned mine land by revegetation: a review, International Journal of Soil Sediment \& Water 3: 13.

Tang, Y.; Mason, R. J.; Wang, Y. 2015. Governments' functions in the process of integrated consolidation and allocation of rural-urban construction land in China, Journal of Rural Studies 42: 43-51. https://doi.org/10.1016/j.jrurstud.2015.09.010

Uyan, M. 2016. Determination of agricultural soil index using geostatistical analysis and GIS on land consolidation projects: a case study in Konya/Turkey, Computers \& Electronics in Agriculture 123: 402-409. https://doi.org/10.1016/j.compag.2016.03.019

Wang, L.; Coles, A. N.; Wu, C.; Wu, P. 2014. Spatial variability of heavy metals in the coastal soils under long-term reclamation, Estuarine, Coastal and Shelf Science 151: 310-317. https://doi.org/10.1016/j.ecss.2014.07.001

Wang, X. J. 2008. Kriging and heavy metal pollution assessment in wastewater irrigated agricultural soil of Beijing's eastern farming regions, Journal of Environmental Science \& Health Part A Toxic/hazardous Substances \& Environmental Engineering 33(6): 1057-1073. https://doi.org/10.1080/10934529809376776

Wilding, L. P. 1985. Spatial variability: its documentation, accommodation and implication to soil surveys, in D. R. Nielsen,
J. Bouma (Eds.). Soil Spatial Variability. Pudoc, Wageningen: Netherlands, 166-193.

Wu, S.; Zhou, S.; Chen, D.; Wei, Z.; Dai, L.; Li, X. 2014. Determining the contributions of urbanisation and climate change to NPP variations over the last decade in the Yangtze River Delta, China, Science of The Total Environment 472: 397-406. https://doi.org/10.1016/j.scitotenv.2013.10.128

Wu, S.; Zhou, S.; Li, X.; Johnson, W. C.; Zhang, H.; Shi, J. 2010. Heavy-metal accumulation trends in Yixing, China: an area of rapid economic development, Environmental Earth Sciences 61: 79-86. https://doi.org/10.1007/s12665-009-0321-0

Yan, J.; Xia, F.; Bao, H. X. H. 2015. Strategic planning framework for land consolidation in China: a top-level design based on SWOT analysis, Habitat International 48: 46-54. https://doi.org/10.1016/j.habitatint.2015.03.001

Zhang, C. 2006. Using multivariate analyses and GIS to identify pollutants and their spatial patterns in urban soils in Galway, Ireland, Environmental Pollution 142: 501-511. https://doi.org/10.1016/j.envpol.2005.10.028

Zhang, J.; Hua, P.; Krebs, P. 2015. The build-up dynamic and chemical fractionation of $\mathrm{Cu}, \mathrm{Zn}$ and $\mathrm{Cd}$ in road-deposited sediment, Science of the Total Environment 532: 723-732. https://doi.org/10.1016/j.scitotenv.2015.06.074

Zhang, Z.; Zhao, W.; Gu, X. 2014. Changes resulting from a land consolidation project (LCP) and its resource-environment effects: a case study in Tianmen city of Hubei province, China, Land Use Policy 40: 74-82. https://doi.org/10.1016/j.landusepol.2013.09.013

Zhao, Y.; Wang, Z.; Sun, W.; Huang, B.; Shi, X.; Ji, J. 2010. Spatial interrelations and multi-scale sources of soil heavy metal variability in a typical urban-rural transition area in Yangtze River Delta region of China, Geoderma 156: 216-227. https://doi.org/10.1016/j.geoderma.2010.02.020

Zheng, R.; Zhao, J.; Zhou, X.; Ma, C.; Wang, L.; Gao, X. 2016. Land use effects on the distribution and speciation of heavy metals and arsenic in coastal soils on Chongming Island in the Yangtze River Estuary, China, Pedosphere 26: 74-84. https://doi.org/10.1016/S1002-0160(15)60024-8

Zhong, X.-L.; Zhou, S.-L.; Zhu, Q.; Zhao, Q.-G. 2011. Fraction distribution and bioavailability of soil heavy metals in the Yangtze River Delta - a case study of Kunshan city in Jiangsu province, China, Journal of Hazardous Materials 198: 13-21. https://doi.org/10.1016/j.jhazmat.2011.10.003 